Original Article (short paper)

\title{
Physical education at the Brazilian Education Association: modern practices of body education in Rio de Janeiro city from 1928 to 1935
}

\author{
Leonardo Mattos da Motta Silva ${ }^{1}$ id, Edivaldo Góis Junior ${ }^{1}$ i[ \\ ${ }^{I}$ Universidade Estadual de Campinas, Faculdade de Educação Física, Campinas, SP, Brasil
}

\begin{abstract}
Aims: This research aimed to understand how Associação Brasileira de Educação (ABE - Brazilian Education Association) constituted visibility strategies for "body education" in Rio de Janeiro city. Method: As for methodology, we conducted documentary research whose primary sources were reports and minutes of ABE, newspapers, magazines, and books. Results: Our time framework was between 1928 and 1935, a period when ABE organized festivities called "Education Weeks" whose target group was students of Rio de Janeiro schools and their parents. Conclusion: It concluded that ABE managed to mobilize schools to demonstrate models of body practices consistent with the principles of a modern school. By alternating strategies such as lectures, courses, public exhibitions, $\mathrm{ABE}$ tried to print in the city the auspices of a modern and sanitized life which had not reached significant portions of the Brazilian population in a country that still claimed a more substantial state intervention in the social field. Similarly, public education was incipient and its project was still being drafted in a debate that involved a multitude of voices and agents with their interests. Between tradition and modernity, it would be difficult to organize discourses in two opposite poles. Finally, as in the discourses, in the field of practices, the mere polarization between tradition and modernity definitively does not explain the alliances and conflicts inherent to the various actors in the construction of greater visibility of "body education" by ABE.
\end{abstract}

Keywords: history of education; physical education; Brazil.

\section{Introduction}

In Brazil, choices involving one's identity currently lie in the meeting of the cultures of European colonizers, of many other European immigrants, of Asians, Africans and indigenous. Therefore, such identity is imagined as an example of immaterial wealth imbued by mestizaje. In seeking historical references of this identity, the discourses surrounding education and health by intellectuals in the 1920s and 1930s are highlighted. In the early twentieth century, Brazilian society grew in complexity with the development of new sectors and social actors in a context of immigration, organization of free labor, growth in medical science and its techniques, the increasing influence of capitalism, and the emergence of left-wing social movements, such as anarchism and communism ${ }^{1}$. In this context, the intellectuals of the period played an important role in the analysis of such changes, and what most interested them was the reason for the difficulties in social development in a country with great economic potential, with numerous natural resources ${ }^{2,3}$. The intelligentsia called for the modernization of Brazil and its main cities, and increasingly defended the link between the health and education of the people.

It was not an original political and intellectual project; the main European cities went through similar changes in the nineteenth century, as described by sociologist Sennett ${ }^{4}$, where the construction of an urban, hygienic, rational civility, according to the prescriptions of physicians and intellectuals was outlined in architecture, in bodies, and urban planning. In Brazil, both in São Paulo and in Rio de Janeiro cities, discourses and practices follow the prerogatives of public hygiene in the early twentieth century $^{5,6}$ and, therefore, do not clash with the projects of European cities such as London and Paris. The largest Brazilian cities tried to reproduce major Western capitals, of course in a limited way, due to their different objective conditions. This representation of a modern city found its adherents in Brazil, with large population clusters that sought to differentiate themselves from the rural setting. For Sevcenko ${ }^{7}$, this period was marked by the introduction of new consumption habits in Brazil, as well as the development of a market of advertising, periodicals, sports practices, music, dance, and cinema.

For Giddens ${ }^{8}$, although risky, in the sense of a binary construction, it is necessary to analyze the abrupt discontinuities between "pre-modern institutions" and modernity; although such studies inevitably produce "oversimplifications", they allow observing the cultural field in a particular way.

Urban Brazil of the early twentieth century was marked by a pre-modern culture with a strong Catholic influence of rural tradition, that is, it was a suitable setting for the dissemination of a modern educational project to be resisted. To succeed, such a project should inculcate scientific rationalities, opposing traditions, rituals, and practices. Nevertheless, since the nineteenth century, that space also knew representations typical of moder- 
nity, which, not abruptly in the Brazilian case, questioned the "trust" of pre-modern culture. Giddens ${ }^{8}$ describes the growth of modernity as opposed to these "trusts", such as tradition and religion, understanding that most situations of modern social life are manifestly incompatible with them.

We think that the process of rupture between modernity and these "trusts" of pre-modern cultures occurred in differentiated forms in various times and spaces. Thus, in Latin America, as well as in urban Brazil in the early twentieth century, modern discourses entered into conflict with religion and tradition, but were also accommodated or even reconciled with pre-modern "trusts". When studying the cultural production due to modernism and socioeconomic modernization in Latin America, Canclini $^{9}$ pointed out the need to go beyond the interpretation that Latin American modernity was late and incomplete in comparison to that of Europe, and to see it as contradictory and hybridized.

These are "Latin American contradictions" caused by modernizing waves in contrast, but in our view also in reconciliation with tradition and religion. Such contradictions allow adjusting our interpretations in order to understand how a modern project would be built in that scenario.

Announced in the name of the "new", modern practices led to individual pleasures, comfort, amusements, which, in the case of Rio de Janeiro city, for example, were more restricted to certain segments of the population. Moreover, in a scenario of contrasts and of a struggle for survival and upward mobility, differences materialized in resistance, feuds, fights, murders, as reported by Chalhoub ${ }^{6}$. Therefore, a transformation of the worker's mentality, the education of the masses in the cities was needed:

This first movement to transform expropriated social agents into employed workers targets the mind or spirit of the free men in question. In fact, one wished free men to internalize the notion that work was a good, the supreme value of the social pact. Note also that this movement of control of spirits and minds clawed its way far beyond the disciplining of time and space of work only - that is, of production -, because the definition of a good man, a working man, included his framing in patterns of family and social conduct compatible with his status of individual integrated to society, to the nation ${ }^{6}$ (p. 49).

However, what we propose in this article is to conduct this interpretation in the sense that rather than reforming only the minds or spirits, they aimed at a change that materialized in bodies through the operationalization of educational strategies related to the constitution of a project characterized by themselves as "new". A key example is the project identified and articulated at Associação Brasileira de Educação [ABE - Brazilian Education Association, civil entity which aimed to influence public education policies and played a significant role in the intellectual debate in Brazil between 1920 and 1930], as Brazilian Escola Nova (New School), which gave importance and centrality to the debate of strategies which focused on "body education" $"$. In this sense, we understand that the word body should be understood here according to its particularities in a given society which details its representations in a perspective of interdependence be- tween individuals in body practices, materialized in hygiene, gymnastics, sports, games, fights, and dances.

We ask what its strategies are. The affirmation of the modern and the clash with tradition, or the accommodation of tradition? Part of the history of education in Brazil ${ }^{11}$ attentively observed the contradictions of the modern discourse of the agents engaged in the strategies of $\mathrm{ABE}$, and described its internal conflicts, which evidence the resistances to what was called upon as "modern" and "new".

Established in 1924, ABE brought together a diverse range of social actors identified by an intellectual elite who believed in the transformation of the country through the democratization of education. Physicians, lawyers, teachers, the military, religious, politicians, and writers of heterogeneous political positions were imbued with the debate on how education could modernize the country. For Carvalho ${ }^{11}$, the group created strategies of dissemination of the "educational cause" as the main national problem. Thus, the discourses of modernization through the education of the people were disseminated in the press and on the radio. A major strategy was the organization of national conferences which produced documents on converging points that instrumentalized public education policies in the country.

Carvalho $^{12}$ emphasizes the limits of opposing modern and traditional to understand the internal clashes of $\mathrm{ABE}$ in the 1920s and 1930s. Is Carvalho's criticism supported when practices are observed? Specifically, how did ABE, which had in its staff educators identified by the term New School, constitute visibility strategies for "body education"? Was it a project identified as modern? One of the most evident strategies lays in an education project which valued the schooling of physical education.

This study had as a hypothesis that people adhered to or resisted the modern discourse of education translated into practices, more specifically, into a "body education" defined not only by European gymnastics but also by modern sports and children's games, depending on the time and space in which such discourse was presented. Not all tensions were dissonances between tradition and modernity. Sometimes they were disputes between actors who defended certain modern practices to the detriment of others. In this sense, examining particularly a modern project of education in Brazil through the representations of physical education advertised by $\mathrm{ABE}$ is an original and relevant key to understanding how the practices were dissonant or consistent with the modern discourse.

Unlike Linhales $^{13}$ - who stressed the negotiations between militaries and educators about a national project of Physical Education regarding gymnastics and sports at ABE -, Soares and Gleyse $^{14}$ - who noted that ABE's educational project was linked to modern principles, emphasizing the importance of physical education for developing hygiene habits and the moralization of customs -, and Góis Junior, Melo and Soares ${ }^{15}$ - who analyzed the oppositions between gymnastics and sport in a body education project of that period -, we problematize ABE's body education project through the contradictions of a Brazilian modernity that was full of particularities and, in Oliven's ${ }^{16}$ terms, creative and dynamic. 
We can then discuss these issues more specifically both in space and in time. In short, how did ABE, which had in its staff educators identified with a modern school project, constitute strategies of visibility for "body education"?

\section{Method}

In terms of methodology, we conducted documentary research whose main sources were reports and minutes of ABE, newspapers, magazines, and books. We focused on the period between 1928 and 1935 when ABE organized festive events called Education Weeks (EW), whose target group was students in Rio de Janeiro city. In the formation of the set of documents, we searched the collections of the National Library of Brazil and ABE located in the city of Rio de Janeiro.

After the corpus of documents was formed, document analysis prioritized the construction of an interpretation that, rather than being purely descriptive, can problematize and interrogate the sources using the categories that emerge from the documentation. The categories were organized in two sets: the first one relates to the practices adopted and proposed by ABE Education Weeks and the second set is linked to the press discourses and their representations of the events and their practices.

Focusing on practices, we can see how pedagogies, services, and even products were resignified, with goals related to body education. In addition, glimpsing such practices through the sources brings us closer to the daily life of those spaces and time, allowing us to understand at what level the education of the body was disseminated, limited or prohibited. Observing practices as a category is key to our research problem, since, for Certeau $^{17}$, practices are inscribed in other social trajectories, comply with criteria, are classified as categories, and aim at changing goals. For Certeau ${ }^{17}$, these questions reveal a formality of practices, which is more or less in accordance with the official or theoretical discourses, and one of the tasks of history is to measure the distance, or relationships, between the formalities of practices and that of the representations that emerge from discourses. In our study, representations emerge from journalistic sources characterized as a major mercantile press, identified with different interests, sometimes liberal, other times authoritarian. In other words, as press historian Capelato ${ }^{18}$ explains, a "big press" produced by more structured companies, with new machinery and technology, advocated a liberal editorial project that presented itself as "unbiased", as representative of public opinion, whose journalists were true "interpreters of the lights".

\section{Results}

\section{Physical education in ABE Education Weeks in Rio de Janeiro}

Specialized historiography devoted to physical education at school has produced several studies linking its institutionalization in the school curriculum with military objectives, nationalisms, and also modern projects of society. Sanitized cities, sanitized bodies due to the belief in pedagogies supported by scientific discourse as a progenitor of safe paths of civility and social progress. In Scotland, Macrae ${ }^{19}$ demonstrated the importance that the government and leading educators gave to physical education in the 1931 curriculum reform. In Turkey, Okay $^{20}$ demonstrated the appreciation of sports parties with the youth and children aimed at stimulating a sense of nationalism in the first decades of the twentieth century. In Sweden, Lundvall ${ }^{21}$ explains that the Swedish gymnastics developed by Per-Henrik Ling in the nineteenth century, and exported to several countries in the world, had objectives strongly linked not only to health but also to militarism. In Argentina, Scharagrodsky ${ }^{22}$ stated that, in the $1920 \mathrm{~s}$, in the face of conflicts on the best physical education method, Argentines opted for a national didactic organization with strong medical influence, allowing and prohibiting specific types of movement. In Germany, Krüger ${ }^{23}$ highlighted the role of gymnastics and its civil associations in the construction of national identity since the nineteenth century. In France, Vigarello ${ }^{24}$ described a very objective, calculated, mechanical gymnastics, whose motto was body control, in slow dissemination in the nineteenth century. In England, even under the influence of modern sports, hygienic gymnastics had its defenders. For Welshman $^{25}$ :

The Board of Education included a medical branch, and it also adopted a more liberal syllabus for physical education that incorporated 'Swedish' exercises and included marching, dancing, skipping, and gymnastic games. Dr. George Newman, its new Chief Medical Officer (CMO), wrote in his report for 1909 that 'physical exercises are now recognised to be a desirable and indeed a necessary part of the school curriculum'. While physical education was not a major item of expenditure, it became an important component of health provision, and indeed by the 1930 s had a disproportionately large place in educational policy and rhetoric (p. 56).

These modes of educating the body, consistent with rational discourses, highlighted European gymnastics. The hope of control over bodily nature gains new nuances from experimentation. Once unveiled, the body-machine could give science the power of remediation of the body's exhaustion. The aspirations were quite optimistic because its supporters strongly believed that the objectivity of positive thinking, superior to the metaphysical one, was able to intervene and modify the body, making it more resistant. Tangible applications in the field of medicine and education, but also in body practices regarded as auxiliaries in the modern project of body-machine, are represented by gymnastics, and also games and sports, which, in the twentieth century, are organized under the term physical education ${ }^{26-28}$.

However, the adoption of the modern discourse of "body education" from rational gymnastics, given its affirmation by means of scientific assumptions arising from experimental physiology and the mechanics of movements also faced resistance. In France, Vigarello and $\mathrm{Holt}^{29}$ indicate that traditional games were very present in the nineteenth century and gymnastics, as a body practice supported by the government, was gradually established in the country. In Brazil, Moreno ${ }^{30}$ reported on resistances to the practice of Swedish gymnastics in schools of Rio de Janeiro in the nineteenth century. Kirk and Twigg ${ }^{31}$ describe the same resistance to Swedish gymnastics because of its predictability and 
monotony in Australia in the 1930s. Also in the Netherlands, Stolk and others ${ }^{32}$ speak of dissidence in the nineteenth century by a minority group of freethinkers who associated physical education with the development of a humanity by means of children's natural needs, and did not see it as formative of citizens able to defend the nation, with bodies trained for a useful life in society. In Korea, however, the contradiction between tradition and modern practices of "body education" is more evident, as Dittrich $^{33}$ describes:

What did "modern", "new" or "western" education mean in late nineteenth-century Korea? It first of all referred to new institutions established by Korean private citizens, foreign missionaries and the Korean government, which offered a new curriculum. This curricular offer was no longer based on Chinese classics but rather on European and American knowledge. It offered the chance to (re)formulate Korean nationalism. New education was seen as a social equaliser overcoming the nobility-commoner divide. The emphasis on uniforms and short hair, military drills, and sports, as well as a new understanding of masculinity which was diametrically opposed to the culture of the Korean nobility, was a further peculiarity of modern education. Values such as military accuracy, punctuality, discipline, and order were at the centre of these changes. Finally, it was shown that new classroom practices characterised new education in Korea. [...] This multitude of voices led to institutional instability and frequent policy changes (p. 282).

Looking specifically at ABE's body education project through its Education Weeks, we interrogated the sources about this opposition between tradition and modernity and whether this interpretation key allows the explanation of a uniform and homogeneous construction of physical education in that period.

ABE was divided by sections: "Primary Education Section", "Secondary Education Section," "Technical and Higher Education Section". There were also other educational topics such as: "Amusements of Children," "Physical Education and Hygiene", "Family Cooperation", "Home Education", "Radio culture" "Care of Abandoned Children", "Professional Education", and "Moral and Civic Education". The "Physical Education and Hygiene Section" (PEHS) operated from May 1926 to June 1937 and held 76 meetings. There were periods of scarcity or absence of meetings: in the years 1927-1928, for example, only four meetings were held, and in 1931-1932 no meetings were held. 1929 was the year with the greatest productivity, with 22 meetings $^{34}$.

ABE had strong knowledge and was well-structured in terms of physical education and hygiene, because it had a section in which it was possible to think, discuss, propose, and carry out actions for such initiatives. In its first year of operation, the president of PEHS was physician Faustino Esponsel, but it was the director of the section, physician Belisario Penna, who made efforts to share medical knowledge, such as the idea of promoting popular conferences ${ }^{35}$.

Advertisements were placed in newspapers such as Correio da Manhã and Jornal do Brasil. There were two types of invitations: one for conferences and another for internal meetings of the section. In the tenth meeting, the president of PEHS, sanitary physician Gustavo Lessa, requested the organization of "the foundations of a program of hygiene and physical education to be adopted throughout Brazil" and "a hygiene improvement course, aimed at primary teachers", with the purpose to increase the knowledge of teachers ${ }^{36}$.

On May 23, 1929, Correio da Manhã newspaper reported that PEHS would hold another course, this time focusing only on physical education, whose tutor would be American professor Helen Paulinson from Women's Christian Association and whose content would be: march tactics; gymnastics; games; regional dances. This course could be attended only by teachers of public primary $\operatorname{schools~}^{37}$ (p. 5). The initiatives appeared to be well articulated to share medical knowledge using physical education as a hygienist strategy ${ }^{38,39}$. In the 18th meeting, it was discussed that the teaching of physical education was not adapted to primary or secondary education, and it was necessary to reorganize $\mathrm{it}^{40}$, which seemed to be coming true, because two days before Correio da Manhã newspaper reported that professor Ambrosio Torres, at the request of PEHS, would hold a conference in which he would expose the foundations of an "eclectic method of national physical education" $" 41$ (p. 6). Hygienist intellectuals of $\mathrm{ABE}$ began to recognize the need to reshape the teaching of physical education; it was necessary to modify it to meet the hygienic assumptions considered imperative for the organization of society ${ }^{34}$.

Given its importance, PEHS guided the program of Education Weeks (EW), the event that brought ABE intellectuals the closest to the school's everyday life. Through lectures, courses, public exhibitions, specific issues were addressed on each day of the week. Health was always represented prominently.

For example, in 1928, the so-called "Health Day" included references to physical exercises in the school context, evidencing a link between the discourses of health and body practices such as hygiene. Correio da Manhã newspaper brought the following:

One of the days of this week, on which we intend to consecrate teaching, will be dedicated to the health of schoolchildren; the matter pleases me more than any other, because I am officially interested in the solution to this problem, which I have taken care of for years - whenever I have had the chance to - certainly without authority but with love. How does the Education Week intend to worship school hygiene? Through the conferences, which serve to disseminate health notions useful to childhood and adolescence; by screening educational movies, and by presenting health platoons in several primary schools ${ }^{42}$ (p. 4).

In Correio da Manhã newspaper, one can observe a more detailed program of "Health Day". This would include: a solemn session at $\mathrm{ABE}$ with the presence of the director of the National Department of Public Health; a conference on "Hygienic Education" by Dr. Belisario Penna; an exhibition on "educational hygiene" at the auditorium of ABE; a reading of advice on "hygiene in primary schools"; the distribution of leaflets and posters on hygiene; a conference on the radio called "Rational Food and Health"; the inclusion of "hygiene films" in the programs of cin- 
emas; and the inclusion of sermons in the church on "hygiene" 43 (p. 6).

If only ABE's official documents were used for this study, we would tend to assert that physical education was not part of the First Education Week. But if one examines different types of sources, one can document the presence of health through the reports from school principals sent to ABE. In them, the number of schools which participated in the EW amounts to 13 . The reports were freely constructed, that is, they were not produced from a predetermined model. Therefore, when we observe the materiality of the documents, we find the manuscript, typewritten and carbon copy texts. Some are very direct in their narratives and others are very comprehensive. In all 13 reports, we have identified the dissemination of hygienic precepts through posters, lectures, poetry, and hymns. In four of the thirteen schools, there was the practice of physical education ${ }^{44}$.

Although they were theoretical, all these actions required the great organization of $\mathrm{ABE}$, and interaction with an extensive network of contacts. For example, in the correspondence exchanged by $\mathrm{ABE}$ with various public and private entities regarding the "Health Day", there is a letter to the Archbishop with a request that the priests give sermons on hygiene. The support requested from the Catholic Church for the dissemination of educational campaigns on hygiene is an important clue to interpret that, in the case of the modern project of education in Brazil, religion was far from confrontation, but close to conformation with science education in the field of "body education".

Despite the combination of Catholic and liberal educators, the thematization of body and health was not immune to criticism from the press. On account of the predominantly theoretical nature of the "Health Day" and, consequently, of the Health Week, it was criticized by newspapers. For example, Correio da Manhã published on September 19, 1928:

Those will be six days when, through conferences, exhibitions, meetings of masters and disciples, of parents and teachers, equally interested in the big problem, we shall hear a lot of deserved noise around a theme which, despite widely used by the mouth and pen of thinkers, continues almost as far from reality among us as the inhabitants of $\operatorname{Mars}^{42}$ (p. 4).

In fact, one observes intervention closer to schools only in achievement reports. One example is the report by Dr. Candido de Mello Leitão, in which a three-line paragraph indicates: At Manoel Cicero school, there was a sports parade in the morning to demonstrate physical culture and gymnastic games with prizes to winners. Also at Afonso Pena school, there was a gymnastics number by 4 th graders and, in the afternoon, poetry and gymnastics presented by students. At Prudente de Moraes school, the first grade also took part in educational games about hygiene objects. At Equador school, there was a recreation with gymnastic exercises every day of the week ${ }^{45}$.

It can be seen through the reports that physical education was present in EW, not in the way hygienist doctors extolled it in their discourse, but secondarily. The silences of the first EW about physical education evidence that it was not perceived as central in the modern project of education of $\mathrm{ABE}$ yet, or that schools were not prepared to receive physical education. What- ever the explanation for these silences, the EW in Brazil distanced itself from the EW in the United States in this regard, because the educational culture of American middle schools gave centrality to a pedagogy of games and physical education ${ }^{46}$.

However, with respect to the Second Education Week, Correio da Manhã newspaper reports: "Today, Thursday, at 5 p.m., at A.B.E. headquarters, located at Rua Chile, $23,4^{\text {th }}$ floor, a meeting with representatives of schools will be held at the physical education section" ${ }^{\prime 47}$ (p. 12). Linhales ${ }^{34}$ studying the schooling of sports, indicates that, in the second edition of EW, physical education, which before "seemed" not to have been included in the event dedicated to education, appears with a day dedicated exclusively to it, during which sport and gymnastics were highlighted. The meeting refers to a tournament of gymnastics and a tournament of American ball which would be held by $\mathrm{ABE}$ with the participation of private and public schools of Rio de Janeiro city in the field of Fluminense Football Club. "The educational institutions which accepted the invitation to take part in the great tournament of gymnastics and American ball" 48 (p. 10) are kindly requested to observe the following program: "2 p.m. - Concentration of students; 2.45 p.m. - Parade and group gymnastics; 3 p.m. - Representation, games, exercises etc., by the institutions present, by order of registration (10 minutes, a non-extendable time period); 5 p.m. - American Ball Championship with registered teams". The newspaper published the instructions of $\mathrm{ABE}$ to the leaders of schools:

- The numbers for which institutions sign up are free-choice and may be chants, representation, exercises, dances, etc., but they cannot exceed 10 minutes.

- For the parade, students will perform with the uniform of the school they attend, which may undergo the necessary modifications for the exercises, and the student in front will carry the school's flag or pennant.

- Group gymnastics will consist of:

- I - Two upper limb exercises: lateral extension of the arms in two stages; lateral vertical extension of the arms, in two stages.

- II - Trunk movement with legs apart sideways and hands-on hips: - extension (backward inclination or flexion) in two stages; forward flexion in two stages; inclination (lateral flexion) in four stages; - rotation in four stages.

- III - Movement of the lower limbs: full flexion of the legs on toes (lowering on heels) in two stages.

- IV - Hops.

- V - Breathing exercises in two stages, elevating heels and arms sideways.

- American ball games will be played by teams of the same sex with the same physical development.

- In the place for the representations, there will be a plan available to schools.

- Group gymnastics will be directed by one of the teachers elected by peers from institutions that take part in the party; the same applies to the referees of American ball games ${ }^{49}$ (p. 7).

It was also agreed that the realization of the set of gymnastics would include all the students present, approximately two 
thousand, an important clue for the interpretation that $\mathrm{ABE}$, through its network of sociabilities, managed to involve a significant part of the schools of Rio de Janeiro city, then the capital of Brazil. The main newspaper in the city publicized the event:

The board of ABE [...], through us, invites Rio de Janeiro society and educational institutions in general to attend this important contest, which great incentives the fitness, moral and intellectual preparation of the Brazilian nation ${ }^{50}$ (p. 12).

The event was to be sponsored by the military police music bands. According to Jornal do Brasil, the bands would grace "such an important party of health, and joy and they are entertainment that will fill with pleasure our cultured society.

According to news after the "Physical Education Day", all occurred according to the plans. The American Ball game "was a great success". About the competition "set of educational gymnastics," it was stated:

In a truly attractive way, these corporations [participating schools] were the main delight of the 4th day of education week, all of which were highly acclaimed for the gracefulness with which they performed, giving a significant expression of physical culture of our capital in all that concerns gymnastics $^{50}$ (p. 12).

Nevertheless, the centrality given to physical education in the 1929 EW also raised criticism. Chrysanthème, the nickname of Cecília Moncorvo Bandeira de Melo Rebelo de Vasconcelos, an important columnist from Rio de Janeiro, did emphasize her impression of the event:

As for the moral education of our childhood, in a receptive state, there also remains much to do. Because, to overcome the pain and setbacks of life, the robustness of a contracted biceps, worthy of admiration and envy, will never suffice. Above all, at this point, when intense malaise and an undefined restlessness devastate children, pushing them to the most sinister solutions, the most magical decisions, one feels that physical culture will certainly sink if moral does not help ${ }^{51}$ (p. 3).

For the columnist, the very possibility of moving, intrinsic to physical education, when added to the "undefined restlessness" essentially natural in children, could lead to catastrophic situations for their bodies. As she pointed out, it could push them "to the most sinister solutions, the most magical decisions". To avoid this, "physical" culture should be aligned with moral education. Therefore, Cecília Moncorvo argues that it is expected that "the flower of the future follows us in the arena of earthly battles", and indicates that it is necessary to clarify that children are "poorly armed for life if provided with muscle culture only". At the end, the author advises:

The week of education, that is, of physical culture, should consider that it is not enough to have a robust body if within that spirit one hallucinates and weakens due to lack of control. Efforts have the strict obligation to converge to this point and look for a better way to invigorate and elevate our childhood, which alcohol and syphilis turn into sexual maniacs from birth [...] And above all, in this dementia epidemic - in which puberty comes with its sad contingent of defenseless and unprepared beings-, gym- nastics, ballet, and foot races will never be enough. We need more useful and stronger drugs ${ }^{51}$ (p. 3).

Cecília Moncorvo criticizes the way "physical culture was presented". At some point, she even calls the event "physical culture week". Her criticism can be supported by a possible centrality of physical education on "Health Day" at the field of Fluminense F.C. With the participation of many schools, the other days of the event may have been played down, which emphasized those modern practices to the detriment of a moral education vaunted by ABE.

In spite of criticism, when EW approached practices, it focused on physical education, representative of a "body education" consistent with the principles of modernity. In the following year, 1930, part of the press still praised the 1929 event. Under the title "Health Day: Physical invigoration of the youth", O Paiz newspaper recalled that "the impression everyone had in October last year still lingers much alive, the grand spectacle of the gymnastics tournament held at the stadium of Fluminense F. C. on Physical Education Day".

In 1930, the day related to physical education, which this time was associated with health, was named "Thursday: Health Day: Health as a good. Physical education, the foundation of health". Professor Ambrósio Torres said he sought to follow the example of the previous year (1929) and "promote large gymnastics set of recreational games, sports games, etc." ${ }^{, 52}$ (p. 4).

The organization followed the same pattern of the previous edition, but this time it began to require not only specific movements of gymnastics, but also recreational games, sports, and different uniforms and programs for each sex. The female uniform would be an "appropriate uniform for exercise, a beanie, beret or cap. The male uniform would consist of: khaki pants, a sports shirt, a white hat (seaman's cap)",53 (p. 7). And again, in order to lead families and society in general to the event, ABE provided students with all the comfort, from booking special seats for them, along with their families, to water supply and health care.

For Correio da Manhã newspaper, the "Health Day" of the Third Education Week, held on May 15, 1930, stood out: "In addition to the brilliance of the other days, we highlight 'Health Day' and its beautiful demonstration of educational physical education [...] at Fluminense's Stadium". The program was as follows:

2.30 p.m. - Concentration of students.

3 p.m. - Parade and group gymnastics

3.30 p.m. - Welcome speech to the youth by Dr. Jorge de Moraes [Dr. Jorge de Moraes was a deputy and president of PEHS of ABE.].

3.40 p.m. - Demonstration of schools that will exhibit special numbers.

4.30 p.m. - Centipede race for male students.

4.50 p.m. - Hanky race for female students.

5.15 p.m. - Student withdrawal from the field and $\operatorname{return}^{54}$ (p. 9).

The newspaper emphasized that all the program was free to the public and especially dedicated to "people interested in the burning issue of the physical education of Brazilians". 54 The event was reported by all major newspapers of the city that day, May 16, 1930. The press stressed that students from all schools 
attended the event, performing "a set of exercises of recreational games and educational gymnastics, and [that] they demonstrated great skill and precision of movements" ${ }^{\prime 55}$ (p. 1-2). O Paiz newspaper proudly informed:

The Brazilian Education Association promoted yesterday in the vast stadium of Fluminense Football Club an interesting party to celebrate the Health Day. It could not have symbolized better the celebration than gathering there a large number of joyful healthy children, bubbling with enthusiasm, as if confirming the intentions of the promoters of the simple assembly of children.

At one point, children from our public educational institutions performed various gymnastic exercises, with the greatest perfection, showing great skill. Then they took part in various recreational games, foot races, etc. The idea could not be more successful ${ }^{56}$ (p. 5).

There was an interruption in the celebrations related to physical education. In the 1931 week, the theme was not included, it was in the week of 1933, and was silenced again in 1935. It was not possible to identify the reason for this silencing; whether, for example, it was related to the internal conflicts of the Physical Education and Hygiene Section, which in some moments meant physicians, the military and teachers linked to Young Men Christian Association (YMCA) with headquarters in São Paulo and Rio de Janeiro had opposite viewpoints on the establishment of a national project of Physical Education, which did not succeed in the period ${ }^{13}$.

In 1933, when the issue returned to the agenda of the EW, it followed the tone of the 1931 edition: it was more "theoretical". There was a greater number of conferences, lectures, and exhibitions. According to the description of ABE, the very program of the day dedicated to health, entitled "Health through education", consisting of an educator showing how one can acquire hygienic habits, attitudes, and ideals in the first periods of life. However, according to the program below, there were also public exhibitions on physical education of schoolchildren $^{57}$, but not as many as in 1930 :

[...] Demonstration of games and regional dances at the stadium of Fluminense F. C. at 2 p.m. by the Superintendence of Physical Education, Recreation and Games. Screening of films on physical education and hygiene in the city's most important movie theaters ${ }^{58}$ (p. 22).

Without giving much information about the afternoon at Fluminense's stadium, Correio da Manhã newspaper stressed that the Superintendence of Physical Education, Recreation and Games of the Education Department, under the direction of North American educator Lois Marietta Williams, linked to YMCA, held a demonstration of games and regional dances, which aroused great interest ${ }^{59}$ (p. 6).

The presence of regional dances evidence that, even in the face of a modern project of education, investing in some traditions through dances would contribute to a sense of belonging linked to national identity as a mosaic of regionalisms guided by "mestizaje", so prized from the 1930s on in the identity of the Brazilians. Nonetheless, it was not possible to identify, for example, how regional dances were addressed, whether they were linked to cultural tradition, capoeira, or indigenous influence.
Because of their absences or silences, we cannot state whether they countered or were hybridized with gymnastics, games, and sports, when we talk about ABE Education Weeks. However, a significant part of the historiography of physical education has argued that gymnastics at school involved popular games, dances and circus activities ${ }^{60-62}$.

In other words, some traditions and practices could be accommodated by modern discourses. Moreover, the increasing influence of the United States in the section due to the participation of teachers from YMCA also meant greater centrality of the educational objectives of the games besides the more methodical gymnastics, because, by combining North American children's games, regional dances and European gymnastics, a "body education" negotiated by several actors but still marked by modern urbanites in those city events was gradually established.

\section{Conclusion}

Taborda de Oliveira and Linhales ${ }^{63}$ argued about the need for further studies about body education and its relations with modernity. The original purpose of this study was to contribute to this question, observing the EWs of ABE.

The research's question was "how did ABE, which had in its staff educators identified with a modern school project, constitute strategies of visibility for 'body education'?” To answer that, the study showed that in the EWs, ABE managed to mobilize schools to demonstrate models of body practices consistent with the principles of a modern school. By alternating strategies such as lectures, courses, public exhibitions, ABE tried to print in the city the auspices of a modern and sanitized life which had not reached significant portions of the Brazilian population in a country that still claimed a more substantial state intervention in the social field. Similarly, public education was incipient and its project was still being drafted in a debate that involved a multitude of voices and agents with their interests.

Looking specifically at ABE's body education project by means of its Education Weeks, we interrogated the sources about the oppositions between tradition and modernity and found different representations of the practices aimed at body education, with support and criticism from the press, as well as adherence of religious to a modern discourse in defense of physical education. In the practices organized by $\mathrm{ABE}$, there was greater visibility of body education strategies based on the modern; on the other hand, they were still not relevant in people's daily lives, for, as a columnist of Correio da Manha ${ }^{42}$ reported in 1928, they were as far from people as the inhabitants of Mars.

Between tradition and modernity, it would be difficult to organize discourses in two opposite poles. In practice, ABE gave visibility to the healthy body through gymnastics, games, and dances. However, this research was limited to the observation of the EW of ABE, and of course, the practices were selected according to the interests of the creators of the event. Thus, in these events, traditional practices linked to black and indigenous cultures were denied by organizers or silenced by the press and by the entity's documents, whereas the scientific, rational, the North American or European were highlighted. In this sense, when we observed the bodily practices of EWs, it was possible 
to notice a centrality of modern and rationalized bodies through public exhibitions that accommodated some traditional practices such as regional dances. We also observed that hygiene education was shaped by the support of the Catholic Church's tradition. However, there was not the same relationship of accommodation with other traditions, such as African and indigenous cultures. Finally, as in the discourses, in the field of practices, the mere polarization between tradition and modernity definitively does not explain the alliances and conflicts inherent to the various actors in the construction of greater visibility of "body education" by ABE.

\section{References}

1. Skidmore T. Preto no Branco. Raça e Nacionalidade no pensamento brasileiro. São Paulo, Paz e Terra, 1989.

2. Leite DM. Caráter Nacional Brasileiro. 3 ed. São Paulo, Pioneira, 1976.

3. Micelli S. Intelectuais à brasileira. São Paulo, Companhia das Letras, 2001.

4. Sennett R. Carne e Pedra: o corpo e a cidade na civilização ocidental. Rio de Janeiro, Record, 1997.

5. Sevcenko N. Orfeu Extático na Metrópole: São Paulo nos frementes anos 20. 4 ed. São Paulo, Companhia das Letras, 1992.

6. Chalhoub S. Trabalho, lar e botequim: o cotidiano dos trabalhadores no Rio de Janeiro da belle époque. 3 ed. Campinas, Editora Unicamp, 2012.

7. Sevcenko N. O prelúdio republicano, astúcias da ordem e ilusões do progresso. In: História da vida privada no Brasil, v. 2. São Paulo: Companhia das Letras; 1998. p. 7-48.

8. Giddens A. As consequências da modernidade. São Paulo, Edunesp, 1991.

9. Canclini NG. Culturas Híbridas: estratégias para entrar e sair da modernidade. São Paulo, EdUSP, 2003.

10. Soares CL. Educação do corpo. In: Dicionário crítico de Educação Física. 3 ed. Ijui,-RS, Editora Unijui; 2015. p. 219-225.

11. Carvalho MMC. Molde nacional e fôrma cívica: higiene, moral e trabalho no projeto da Associação Brasileira de Educação (1924-1931). 4 ed. Bragança Paulista, EDUSF, 1998.

12. Carvalho MMC. O novo, o velho, o perigoso: relendo a cultura. Cadernos de Pesquisa 1989; 71: 29-35.

13. Linhales MA. Militares e educadores na Associação Brasileira de Educação: circulação de interesses em torno de um projeto para a educação física nacional (1933-1935). Educ. rev. 2009; 33: 7591.

14. Soares CL, Gleyse J. La constitution d'une pédagogie de l'hygiène au Brésil comme système de contrôle (fin du XIXe siècle 1931). Staps. 2006; 74(4): 47-67.

15. Góis Jr, Melo, Soares. Para a construção da nação: debates brasileiros sobre educação do corpo na década de 1930. Educ. Soc. 2015 ; 36 (131): 343-360.

16. Oliven R. Cultura e modernidade no Brasil. São Paulo Perspec. 2001; 15 (2): 3-12.

17. Certeau M. A escrita da história. Rio de Janeiro, Forense, 2011.

18. Capelato MH. O controle da opinião e os limites da liberdade: imprensa paulista (1920-1945). Rev. Bras. Hist. 1992; 12 (23): 55-75.

19. Macrae EHR. Exercise and education: facilities for the young female body in Scotland, 1930-1960. History of Education. 2012; 41(6): 749-769.
20. Okay C. Sport and Nation Building: Gymnastics and Sport in the Ottoman State and the Committee of Union and Progress, 1908-18. Inter. J. History of Sport. 2003; 20 (1): 152-156.

21. Lundvall S. From Ling Gymnastics to Sport Science: The Swedish School of Sport and Health Sciences, GIH, from 1813 to 2013. Inter. J. History of Sport. 2015; 32 (6): 789-799.

22. Scharagrodsky P. El discurso médico y su relación con la invención del oficio de 'educador físico': entre la heteronomia solapada y la autonomía vigilada (Argentina, 1901-1931). In Miradas médicas sobre la cultura física en Argentina (1880-1970). Buenos Aires, Prometeo; 2014. p. 101-148.

23. Krüger M. Body Culture and Nation Building: The History of Gymnastics in Germany in the Period of its Foundation as a Nation-State. Inter. J. History of Sport. 1996; 13 (3): 409-417.

24. Vigarello G. A invenção da ginástica no século XIX: movimentos novos, corpos novos. Rev. Bras. Ciênc. do Esporte. 2003; 25 (1): 9-20.

25. Welshman J. Physical culture and sport in schools in England and Wales, 1900-40. Inter. J. History of Sport. 1998; 15 (1): 54-75.

26. Gois Jr. E, Terra VD, Soares CL. Corpo-máquina: diálogos entre discursos científicos e a ginástica. Movimento. 2015; 21 (4): 973-984.

27. Gleyse J, Pigeassou C, Marcellini A, De Léséleuc E, Bui-Xuânet G. Physical Education as a Subject in France (School Curriculum, Policies and Discourse): The Body and the Metaphors of the Engine-Elements Used in the Analysis of a Power and Control System during the Second Industrial Revolution. Sport, Educ. and Society. 2002; 7 (1): 5-23.

28. Rabinbach A. The human motor: fatigue, energies and the origins of modernity. Los Angeles, University of California Press, 1992.

29. Vigarello G, Holt R. O corpo trabalhado - Ginastas e esportistas no século XIX. In História do Corpo, v. 2. Rio de Janeiro, Vozes; 2008. p. 393-478.

30. Moreno A. O Rio de Janeiro e o corpo do homem fluminense: o 'não lugar' da ginástica sueca. Rev. Bras. de Ciênc. Esporte. 2003; 25 (1): 55-68.

31. Kirk D, Twigg K. The militarization of school physical training in Australia: the rise and demise of the Junior Cadet Training Scheme, 1911-31. History of Education. 1993; 22 (4): 391-414.

32. Stolk V, Los W, Veugelers W. Physical education for citizenship or humanity? Freethinkers and natural education in the Netherlands in the midnineteenth century. History of Education. 2012; 41 (6): 733-748.

33. Dittrich K. The beginnings of modern education in Korea, 1883-1910. Paedagog Hist. 2014; 50 (3): 265-284.

34. Linhales MA. A escola e o esporte: uma história de práticas culturais. São Paulo, Cortez, 2009.

35. Associação Brasileira de Educação. Atas da Seção de Educação Física e Higiene, Acervo ABE, 1927.

36. Associação Brasileira de Educação. Atas da Seção de Educação Física e Higiene, Acervo ABE, 1928.

37. Associação Brasileira de Educação. Correio da Manhã 1929; May 23: 5.

38. Soares CL. Educação Física: raízes europeias e Brasil. Campinas, Autores Associados, 1994.

39. Góis Jr E, Lovisolo HR. Descontinuidades e continuidades do movimento higienista no Brasil do século XX. Rev. Bras. Ciênc. Esporte. 2003; 25(1): 41-54.

40. Associação Brasileira de Educação. Atas da Seção de Educação Física e Higiene, Acervo ABE, 1929.

41. Conferencias. Correio da Manhã 1929; July 4: 6.

42. Velloso AL. Semana da Educação. Correio da Manhã 1928; September 19: 4. 
43. O Dia da Saúde. Correio da Manhã 1928; October 7: 6.

44. Associação Brasileira de Educação. Relatório do Dia da Saúde, Acervo ABE, 1928

45. Associação Brasileira de Educação. Relatório do Dia da Saúde, Acervo ABE, 1928.

46. National Education Association. American education week history. Available from: http://www.nea.org/grants/61038.htm [accessed 2018 July 10].

47. Na Associação Brasileira de Educação. Correio da Manhã 1929, September 3: 12.

48. A Semana de Educação. Jornal do Brasil 1929; October 9: 10.

49. Associação Brasileira de Educação. Correio da Manhã 1929; October 4: 7 .

50. Associação Brasileira de Educação. Jornal do Brasil 1929; October 3: 12 .

51. Chrysanthème, A Semana. O Paiz 1929; October 13: 3.

52. O Dia da Saúde, O Paiz 1930; February 7: 4.

53. O Dia da Saúde, O Paiz 1930; April 26: 7.

54. Terceira Semana de Educação. Correio da Manhã 1930; May 16: 9.

55. O Dia da Saúde. Diário Carioca 1930; May 16: 1-2.

56. A 3ª. Semana de Educação. O Paiz 1930; May 16: 5.

57. Associação Brasileira de Educação. Programa de atividades da 5a Semana de Educação, Acervo ABE, 1933.

58. Departamento de Educação. Jornal do Brasil 1933; November 19: 22 .

59. Semana da Educação, Correio da Manhã 1933; November 22: 6.

60. Soares CL. Imagens da educação no corpo: estudo a partir da ginástica francesa no século XIX. Campinas, Autores Associados, 1998.

61. Vago TM. Cultura escolar, cultivo de corpos: educação physica e gymnastica como práticas constitutivas dos corpos de crianças no ensino público primário de Belo Horizonte (1906-1920). Bragança Paulista, Edusf, 2002.
62. Melo VA. A dança nas escolas do Rio de Janeiro do século XIX (décadas de 1820-1860). Rev. Bras. Hist. Educ. 2016; 16: 303332.

63. Taborda de Oliveira MA, Linhales MA. Pensar a educação do corpo na e para a escola: indícios no debate educacional brasileiro (1882-1927). Rev. Bras. Educ. 2011; 16 (47): 389-408.

\section{Acknowledgments}

This work was supported by São Paulo Research Foundation (FAPESP), under Grant [2016/00617-6]. This study was financed in part by the Coordenação de Aperfeiçoamento de Pessoal de Nível Superior - Brasil (CAPES) - Finance Code 001 BN - National Library of Brazil. ABE - Brazilian Education Association

\section{Corresponding author}

Edivaldo Góis Junior.

Universidade Estadual de Campinas.

Faculdade de Educação Física.

Av. Érico Veríssimo, 701. Cidade Universitária.

Campinas, SP, Brazil.

E-mail: egoisjunior@gmail.com

Manuscript received on December 28, 2018

Manuscript accepted on August 23, 2019

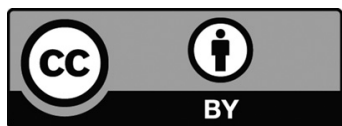

Motriz. The Journal of Physical Education. UNESP. Rio Claro, SP, Brazil eISSN: 1980-6574 - under a license Creative Commons - Version 4.0 